Madrygal. Revista de Estudios Gallegos

ISSN: 1138-9664

\title{
Xesús Alonso Montero e Galicia
}

Carmen Mejía Ruiz ${ }^{1}$

Falar do profesor Xesús Alonso Montero é para nós una ledicia e un compromiso. Este volume que presentamos e que dedicamos ao profesor Alonso Montero é o resultado dunha parte do traballo que durante tres anos (20152018) levamos a cabo como xunta directiva da Asociación Internacional de Estudos Galegos e que finalizamos coa celebración do Congreso internacional que tivo lugar en setembro do 2018 na Universidade Complutense de Madrid. Daquela, o profesor Alonso Montero estaba convidado para dar a lección maxistral de clausura de tan relevante evento no Ateneo de Madrid, un espazo adecuado polo seu vencello coas letras galegas. Desfortunadamente, non puido estar con nós por motivos coñecidos por todos, a grave enfermidade de Victoria Álvarez Ruiz de Ojeda, a súa muller. Por iso, entre moitos máis motivos, ofrecemos este volume como merecida homenaxe ao Mestre de todos nós, dos que o tratamos persoalmente e dos que o coñecen polos seus traballos arredor de Galicia. Estou segura que os colaboradores e colaboradoras deste volume coñecen a pluma do Mestre.

A figura de Alonso Montero garda unha variedade de facetas diversas e atractivas que se caracterizan polo seu compromiso coa terra, coa terra galega. Cando tiven que escoller no ano 1987 materias para cubrir a miña dedicación docente universitaria, os estudos que me axudaban, que me ilustraban para as miñas clases, eran fundamentalmente os do profesor Alonso Montero. Aqueles sobre Rosalía de Castro, sobre Curros Enríquez, sobre Celso Emilio Ferreiro na editorial Akal. Os estudos de sociolingüística galega, sobre os perigos que o profesor prevía para a lingua galega alá polos anos setenta. É moi significativo comprobar como as novas xeracións xa non coñecen $O$ informe dramático da lingua galega, un texto que eu traballaba nas aulas cos meus estudantes do nocturno e que tanta inquietude nos provocaba a aqueles que nos identificabamos e traballabamos a prol das linguas minoritarias. Que os novos non coñezan este estudo provócame desasosego, pero debo recoñecer que pode ser un sinal de que a lingua galega segue adiante "a pesar dos pesares". Estes estudos e moitos máis son un botón de mostra do traballo inxente e xeneroso que o Mestre fixo e segue a facer hoxe pola súa terra, por Galicia. Eu, persoalmente, penso que esa dedicación e xenerosidade son marcas da súa orixe. $\mathrm{O}$ traballo que desde neno el vía facer aos seus pais, o contacto cos labregos, coa lingua deles, xerou esa inquedanza cara aos demais e o seu compromiso social e político. Ese compromiso que se percibe nos seus estudos e que eu recibín, como o resto dos profesores e investigadores, tan xenerosamente e que me axudaron a percibir a realidade de Galicia á maneira do Mestre.

$\mathrm{O}$ apoio do profesor Alonso Montero que sempre tivemos e temos no Centro de Estudos Galegos da Universidade Complutense é incondicional. Calquera proposta que lle facemos é recibida con estusiasmo. Madrygal, 1 Universidad Complutense de Madrid. Departamento de Estudios Románicos, Franceses, Italianos y Traducción.
Correo-e: cmejiaru@ucm.es; https://orcid.org/0000-0002-2444-8817. 
esta revista de estudos galegos, que tanto traballo xera e que sae regularmente grazas á xenerosidade de Ricardo Pichel, leva o selo do profesor Alonso Montero na que colabora, sempre, con interese e agarimo. Velaí a súa man, a súa traxectoria. Podería falar da faceta de Alonso Montero como rebelde, como comunista, segundo el "o último comunista do mundo". Poderíalle dedicar un espazo ao poeta, pero habería que facer unha tese de doutoramento para poder mostrar con xustiza esas facetas que engloba a figura do Mestre. Este "mestre das palabras", das palabras escritas e faladas que engaiolan, que arrebatan a atención e que conmoven a todos aqueles que o escoitamos, lemos e estudamos. Polo tanto, soamente me resta ofrecerlle en nome de todos os membros do Consello editorial e de redacción de Madrygal, no meu nome propio e no de Ricardo Pichel e Ana Acuña, almas deste volume, a presente Homenaxe. Graciñas sempre Mestre e que "cante o merlo". 